\title{
Effects of Teaching Approach Based on Three-dimensional Grammar on Grade Eight Students' Acquisition of English Phrasal Verbs
}

\author{
Mingxing Tao \\ School of Foreign Languages, Hunan University, Changsha, Hunan Province, 410082, China \\ Jiaxin Wang \\ School of Foreign Languages, Hunan University, Changsha, Hunan Province, 410082, China
}

\begin{abstract}
Phrasal verbs, an essential but complex aspect of English vocabulary, are difficult for Chinese EFL learners to acquire, whose first language lacks of phrasal verbs. This quasi-experiment explores the effectiveness of the teaching approach based on three-dimensional grammar on the acquisition of English phrasal verbs by Chinese middle school students compared with that based on conceptual metaphor theory. The finding is that there is a significant difference between the effect of three-dimensional grammar teaching and that of conceptual metaphor teaching, and the former is of great benefit for learners to acquire English phrasal verbs.
\end{abstract}

Index Terms - English phrasal verbs, three-dimensional grammar, Chinese EFL learners

\section{INTRODUCTION}

Wilkins (1972) once stated that "Without grammar very little can be conveyed; without vocabulary nothing can be conveyed" (p. 111). It can be seen that vocabulary plays an important role in language teaching and learning. Phrasal verbs, integral to English vocabulary, defined as the verb plus particle combinations by Bolinger (1971), present multiple challenges for second language (L2) learners of English, which are related to the influence of the learners' first languages (L1s), inappropriate teaching methods, and the complexity of phrasal verbs themselves. In addition, only a few languages have phrasal verbs, which undoubtedly limits the possibility of acquiring for those learners whose first language lacks of phrasal verbs. There is no phrasal verb in Chinese, so it is difficult for Chinese EFL learners to learn English phrasal verbs. Therefore, this paper attempts to explore a more effective approach for Chinese EFL learners to acquire English phrasal verbs.

\section{THEORETICAL FRAMEWORK}

This paper adopts three-dimensional grammar and output driven hypothesis as its theoretical foundations.

\section{A. Three-dimensional Grammar}

Larsen-Freeman (2003) argued that when learning grammar, apart from knowing their forms and meanings, it is more important to know when and why to use them, that is, the combination of form, meaning and use, which are interrelated and interacted with each other. So she put forward the theory of three-dimensional grammar (2005), which not only focuses on form and meaning, but also attaches great importance to learners' ability of usage.

The three dimensions are depicted in Figure 1.

The first dimension is the form of a language, which includes both visible and invisible units: phonology, graphology, morphology and syntax.

The second dimension is the meaning of a language, which relates to semantics. It mainly refers to the meaning of language forms, which can be found in dictionaries.

The third one is the use of a language, which can be referred to pragmatics. The basic units of it are social functions (such as promising, invitation, agreement and apologizing) and discourse patterns (such as those that contribute to the cohesion within texts).

These three dimensions are interrelated and interacted with each other. 


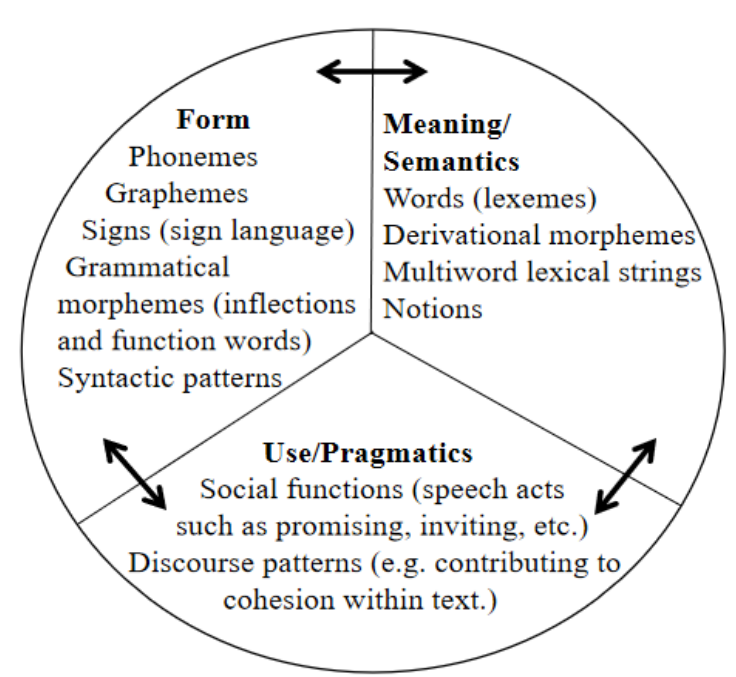

Figure 1. Prototypical Units of the Three Dimensions (Larsen-Freeman, 2005)

Larsen-Freeman stresses all the necessity of form, meaning and use, which can be indicated by three questions, namely: how the grammar is formed (form), what does the grammar mean (meaning) and when and why the grammar is used (use). The following figure clearly demonstrates the explanation of the three dimensions.

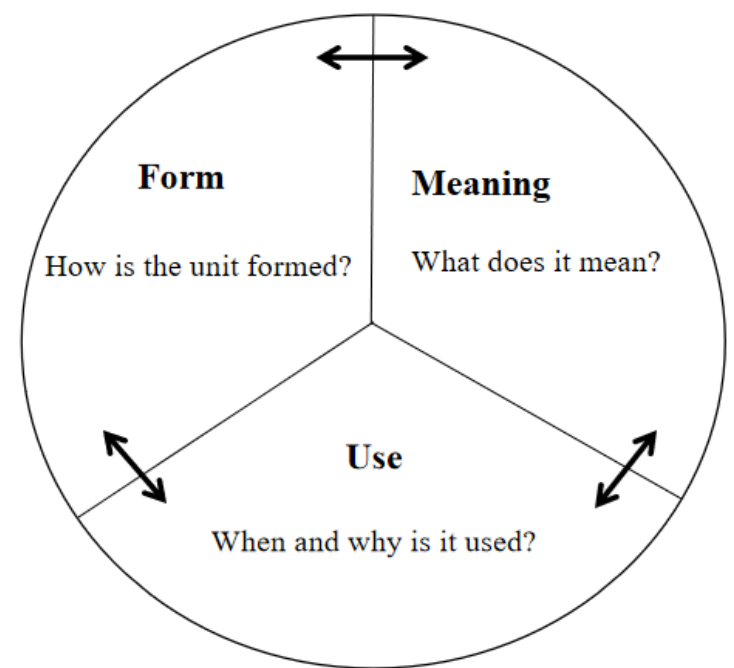

Figure 2. Explanation of the Three Dimensions (Larsen-Freeman, 2005)

In summary, the three dimensions exist in a dynamic and holistic system. The three arrows respectively connect one part of the whole with others, which means changes in any one dimension will influence the other two.

\section{B. Output Driven Hypothesis}

As an improvement of Krashen's input hypothesis, Swain (1985) proposed comprehensible output hypothesis, and believed that the output could not only improve language fluency, but also have the functions of noticing and triggering, hypothesis-testing and meta-language so as to improve the accuracy of the second language.

Inspired by Swain's output hypothesis, Wen Qiufang (2013) put forward output driven hypothesis, which consists of three sub-hypotheses. Firstly, from the perspective of psycholinguistics, this hypothesis regards that output is a greater driving force for the development of foreign language ability than input. Secondly, from the perspective of the needs of workplace English, this hypothesis indicates that the development of students' expressive skills of speaking, writing and translating is more socially functional than the development of listening and reading skills, especially the oral and written translation skills. Thirdly, as for foreign language teaching, the hypothesis holds that the output-oriented comprehensive teaching approach is more effective than the single or individual skill training method, which is more suitable for students' future needs.

Both three-dimensional grammar and output driven hypothesis emphasize the use of language.

\section{Previous Studies on the Teaching of Phrasal Verbs}

There are two main approaches to teach vocabularies/phrasal verbs: form-focused instruction and meaning-focused 
instruction.

Form-focused instruction refers to "any planned or incidental instruction activity that is intended to induce language learners pay attention to linguistic form" (Ellis, 2001, p.1-2). Focus-on-forms (FonFs) is often connected with traditional grammar-based L2 instruction, where the typical procedure of teaching is first presenting the structures and rules of the objects, then followed by drills, memorizing through repetition, and translating the learned knowledge (Sun \& Wang, 2003; Chan \& Liou, 2005).

But the effect of form-focused instruction is not so good, and Chinese EFL learners still have difficulty in acquiring vocabularies/phrasal verbs, so it is still needed to explore other effective approaches (Wang, 2020; Gao, 2021). Then, some researchers turn to meaning-focused instruction. Long (1991) agreed that the focus of L2 learning should be on meaning but acknowledged the need for some focus on grammar, which should be within the context of meaning-based communicative activities and interactions ( $\mathrm{Lu}, 2021)$.

In contrast to the traditional theory of phrasal verbs, which holds that one phrasal verb is an inseparable unit and there is no other special meaning of the particle (Gibbs, 1990), that phrasal verbs are learned as whole units (Nippold, 1998) and that they are usually acquired by mechanical memory, cognitive linguistics believes that phrasal verbs are separable as well as analyzable, and each particle of phrasal verbs has many other meanings which originated from its basic meaning (Lakoff, 1987; Langacker, 1992; Boers, 2004). Teaching vocabularies based on conceptual metaphor theory is an effective method (White, 2012; Veliz, 2017; Li, 2017; Luo, 2020), which belongs to meaning-focused instruction.

\section{RESEARCH QUESTIONS}

Since three-dimensional grammar teaching has a significant effect on students' acquisition of grammar (Lightbown, 2000; Liviero Sara, 2016; Hao, 2018; Song, 2019), and conceptual metaphor teaching is beneficial for acquiring phrasal verbs, then between teaching approaches based on three-dimensional grammar and conceptual metaphor theory, which approach is more effective for Chinese EFL learners to acquire phrasal verbs?

The research questions are posed as follows:

1. What effect does three-dimensional grammar teaching have on the acquisition of English phrasal verbs by Chinese grade eight students compared with that of conceptual metaphor teaching?

2. What are the learners' perceptions towards the teaching approach based on three-dimensional grammar?

\section{THE EXPERIMENT}

\section{A. Participants}

Three intact classes of Grade Eight in Jiaozuo No.17 Middle School are chosen for this study, in which students are all Chinese native speakers. All these three classes are taught by the same teacher both in Grade Seven and Grade Eight. One class is used for the pilot experiment and the other two classes are for the formal experiment.

Students are asked to take Nation's VLT (Vocabulary Level Test) first within 15 minutes (the full score is 18). Nation's VLT includes five different word-frequency levels, and according to The Academic Test for the Junior High School Students of English in 2020, students need to acquire about 1600 words, therefore, the 2000 word-level is chosen for this study.

TABLE 1.

DESCRIPTIVE STATISTICS OF 3 Classes

\begin{tabular}{lllll}
\hline & Statistics of Class & & Tests of Normality & \\
& $\mathrm{N}$ & Mean & K-S Sig. & S-W Sig. \\
\hline Class 1 & 55 & 12.636 & .067 & .133 \\
Class 2 & 54 & 12.593 & .059 & .109 \\
Class 3 & 55 & 12.436 & .065 & .160 \\
\hline
\end{tabular}

In Table 1, it can be seen that the Sigs of the three classes are $0.067,0.059$ and 0.065 respectively, which are all larger than 0.05, and in Table 2, the four Sigs are all larger than 0.05 as well, which mean that all these statistics of the three classes are in accordance with normal distribution and they have the same variance. Therefore, the scores of these students can be statistically analyzed by one-way ANOVA.

TABLE 2.

TEST OF VARIANCE

\begin{tabular}{llllll}
\hline & & Levene Statistic & df1 & df2 & Sig. \\
\hline \multirow{5}{*}{ Scores } & Based on Mean & .834 & 2 & 161 & .436 \\
& Based on Median & .729 & 2 & 161 & .484 \\
& Based on Median and with adjusted & .729 & 2 & 159.192 & .484 \\
& df & Based on trimmed mean & .839 & 2 & 161 \\
\hline
\end{tabular}

As indicated in Table 3, there is no significant difference between these three classes $(\mathrm{p}=0.838>0.05)$, which shows that students in these three classes have the same range of English vocabulary. 
TABLE 3.

\begin{tabular}{llllll}
\hline \multicolumn{5}{c}{ ONE-WAY ANOVA OF 3 ClASSES } \\
\hline Between Groups & Sum of Squares & df & Mean Square & F & Sig. \\
Within Groups & 1.215 & 2 & .607 & .177 & .838 \\
Total & 551.292 & 161 & 3.424 & & \\
\hline
\end{tabular}

Before the experiment, students in two experimental classes are required to finish the phrasal verbs test (the full score is 24) within 15 minutes. The phrasal verbs test including 12 questions is conducted to check participants' command of English phrasal verbs. Students with scores higher than 12 are excluded, and the remaining students with low scores are the participants in the formal experiment. Thus, in fact, the number of participants is 99: there are 44 in Class 1 and 45 students in Class 2, whose scores are valid data.

TABLE 4.

DESCRIPTIVE STATISTICS OF 3 CLASSES

\begin{tabular}{lllll}
\hline & Statistics of Class & & Tests of Normality & \\
& $\mathrm{N}$ & Mean & K-S Sig. & S-W Sig. \\
\hline Class 1 & 44 & 5.681 & .056 & .121 \\
Class 2 & 45 & 6.002 & .065 & .157 \\
Class 3 & 45 & 6.178 & .061 & .103 \\
\hline
\end{tabular}

As shown in Table 4, all K-S Sigs are larger than 0.05, which implies that all these statistics are in accordance with normal distribution.

TABLE 5.

TEST OF VARIANCE

\begin{tabular}{|c|c|c|c|c|c|}
\hline & & Levene Statistic & df1 & $\mathrm{df} 2$ & Sig. \\
\hline \multirow{4}{*}{ Scores } & Based on Mean & .266 & 2 & 131 & .767 \\
\hline & Based on Median & .329 & 2 & 131 & .720 \\
\hline & $\begin{array}{l}\text { Based on Median and with } \\
\text { adjusted df }\end{array}$ & .329 & 2 & 128.812 & .720 \\
\hline & Based on trimmed mean & .259 & 2 & 131 & .772 \\
\hline
\end{tabular}

The four Sigs in Table 5 are $0.767,0.720,0.720$ and 0.772 respectively, which reveal that the three classes share the same variance. Thus, the data can be statistically analyzed by one-way ANOVA.

TABLE 6.

ONE-WAY ANOVA OF 3 CLASSES

\begin{tabular}{llllll}
\hline & Sum of Squares & df & Mean Square & F & Sig. \\
\hline Between Groups & 5.608 & 2 & 2.804 & .422 & .657 \\
Within Groups & 870.123 & 131 & 6.642 & & \\
Total & 875.731 & 133 & & & \\
\hline
\end{tabular}

As shown in Table 6, there is no statistical difference between these three classes $(p=0.657>0.05)$. The 134 students are not familiar with the target phrasal verbs, therefore, the experiment can be carried out with these participants.

\section{B. Materials}

With a view not to disturb the normal teaching contents and progress, the materials used in the experiment are selected from the participants' English textbook Go for it, published by People's Education Press. Target materials include particles "up" and "out", and the relevant phrasal verbs are cheer up, give up, put up, call up, fix up, set up, give out, try out, hand out, take out, stay out and help out from Unit 2 and Unit 3.

\section{Instruments}

On the basis of quantitative research method, the results of the experiment are analyzed through SPSS 22.0. There are two instruments adopted in this experiment to make comparison between Class 1 and Class 2: tests and questionnaire.

Tests

The immediate posttest is taken to reflect the acquisition of target phrasal verbs of participants after being instructed with different approaches in the two classes. It is made up of two parts: 15 choice questions and 15 translation questions. Question 5, 10 and 15 of each part are distractions, which do not include the target phrasal verbs, so the scores are not counted. The immediate posttest should be finished in 40 minutes and students can get two points for getting the right answer.

All the participants are given 40 minutes to complete the delayed posttest after the teaching period of the experiment (two weeks later). Compared with the immediate posttest, the content of the delayed posttest is the same, but the sequence of the questions is changed randomly in order to minimize the effect of the immediate posttest on the delayed posttest, with an aim to investigate the effect of the two different teaching approaches on the retention of phrasal verbs.

Questionnaire 
A questionnaire is given out after the experiment based on the questionnaires from Hao (2018) and Song (2019) in order to get participants' feedback of three-dimensional grammar teaching. There are 15 choice questions, and according to the Likert Scale, options from 1 to 5 represent a tendency from "strongly disagree" to "strongly agree". Questions 1-3 are mainly about students' attitudes towards the learning and teaching of phrasal verbs. The next five questions aim at investigating the perceptions of participants towards three-dimensional grammar teaching. Then questions 9-12 intend to figure out whether three-dimensional grammar teaching affects participants' learning of phrasal verbs. The last three questions reveal participants' general feelings and hopes towards the teaching and learning in English lessons.

\section{Procedure}

The experiment was carried out in March and April 2021. The teaching procedure of the experiment is consistent with the standard teaching schedule in Jiaozuo No.17 Middle School. In addition, given the number and the location of phrasal verbs in the textbook, the experiment lasted for about two months. There are classroom teaching, the immediate posttest and the delayed posttest in both classes.

In the normal teaching process, when target phrasal verbs are encountered in Class 2, with three-dimensional grammar teaching, the teacher first explains the definition and form of the phrasal verb, and then shows the meaning of the particle and various meanings of the phrasal verb through some examples and interactions. Secondly, the teacher requires students to work in groups to practice the phrasal verbs they have just learned in their own situational dialogues. Finally, one or two group will be chosen to show themselves.

While in Class 1, based on conceptual metaphor teaching, the teacher first shows the students the picture of the particle of the phrasal verb, for instance, the basic meaning of the particle "up" means more and to a higher position, which can be depicted as the following picture (Figure 3). Based on the picture, students can easily figure out that "put up" means putting something from a lower place to a higher place. Then the teacher asks students to draw their own pictures of the meanings of the phrasal verbs and share them with the classmates together. Time spent in teaching phrasal verbs in these two classes is the same.

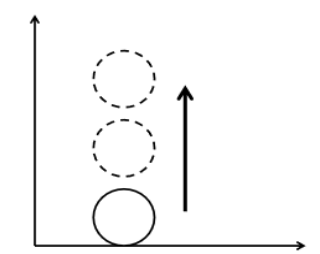

Figure 3. Picture for comprehending "up".

After teaching all the target phrasal verbs, the participants need to complete the immediate posttest in the following self-study class. And after two weeks, the delayed posttest should to be finished as well.

\section{E. Results}

\section{Results of Immediate Posttests}

The reliability of the two parts of the immediate posttest is 0.803 and 0.718 respectively, indicating that the test has a high reliability and can be used as an instrument to test participants' learning results.

TABLE 7.

DESCRIPTIVE STATISTICS OF 2 CLASSES

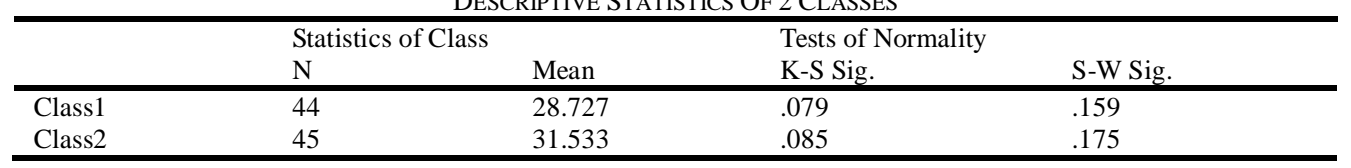

In Table 7, the Sigs of the two classes are 0.079 and 0.085 respectively, which are all larger than 0.05 , so they are in accordance with normal distribution. Besides, the Sig. in Table 8 is 0.904 , which means the two classes share the same variance. Therefore, the data can be statistically analyzed by independent-samples t test so as to make sure that there is statistical significance between Class 1 and Class 2 in immediate posttests. 
TABLE 8.

INDEPENDENT-SAMPLES T TEST OF 2 DIFFERENT APPROACHES

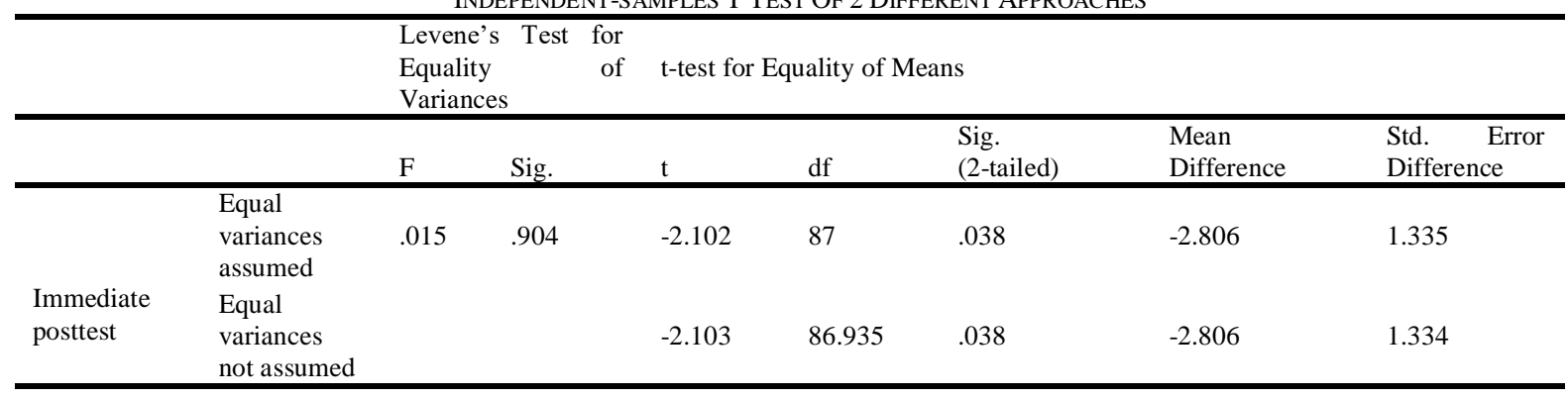

According to Table 8, the Sig. (2-tailed) is 0.038, which indicates a significant difference between Class 1 and Class 2, while the mean score of Class 2 is larger than that of Class 1 in Table 7 . It can be concluded that three-dimensional grammar teaching is more effective in instructing Chinese middle school students to acquire English phrasal verbs than the method based on conceptual metaphor theory.

Results of Delayed Posttests

All statistics in Table 9 are in accordance with normal distribution (the Sigs of the two classes are 0.081 and 0.067 respectively, which are all larger than 0.05$)$.

TABLE 9.

DESCRIPTIVE STATISTICS OF 2 Classes

\begin{tabular}{lllll}
\hline & \multicolumn{2}{l}{ Statistics of Class } & \multicolumn{2}{c}{ Tests of Normality } \\
& $\mathrm{N}$ & Mean & K-S Sig. & S-W Sig. \\
\hline Class1 & 44 & 25.568 & .081 & .152 \\
Class2 & 45 & 29.755 & .067 & .120 \\
\hline
\end{tabular}

What is more, the Sig. in Table 10 is 0.697 , which implies the two classes have the same variance. So these statistics can be analyzed by independent-samples $t$ test.

TABLE 10.

INDEPENDENT-SAMPLES T TEST OF 2 DIFFERENT APPROACHES

\begin{tabular}{|c|c|c|c|c|c|c|c|c|}
\hline & & $\begin{array}{l}\text { Leve } \\
\text { Equa } \\
\text { Varia } \\
\end{array}$ & $\begin{array}{r}\text { Test for } \\
\text { of }\end{array}$ & \multicolumn{4}{|c|}{ t-test for Equality of Means } & \multirow[b]{2}{*}{$\begin{array}{l}\text { Std. Error } \\
\text { Difference }\end{array}$} \\
\hline & & $\mathrm{F}$ & Sig. & $\mathrm{t}$ & $\mathrm{df}$ & Sig. (2-tailed) & $\begin{array}{l}\text { Mean } \\
\text { Difference }\end{array}$ & \\
\hline & $\begin{array}{l}\text { Equal variances } \\
\text { assumed }\end{array}$ & .153 & .697 & -2.008 & 87 & .048 & -2.775 & 1.382 \\
\hline $\begin{array}{l}\text { Delayed } \\
\text { posttest }\end{array}$ & $\begin{array}{l}\text { Equal variances } \\
\text { not assumed }\end{array}$ & & & -2.006 & 86.369 & .048 & -2.775 & 1.383 \\
\hline
\end{tabular}

According to Table 10, the Sig. (2-tailed) is 0.048 , which reflects that there is a significant difference between the two classes, indicating that three-dimensional grammar teaching is significantly better than conceptual metaphor teaching for phrasal verbs retention.

TABLE 11.

PAIRED-SAMPLES T TEST OF 2 DIFFERENT APPROACHES

\begin{tabular}{|c|c|c|c|c|c|c|c|}
\hline & & \multicolumn{6}{|c|}{ Paired Differences } \\
\hline & & Mean & Std. Deviation & & $\mathrm{t}$ & df & Sig. (2-tailed) \\
\hline \multirow{6}{*}{$\begin{array}{l}\text { Conceptual } \\
\text { metaphor } \\
\text { teaching } \\
\text { (Class 1) } \\
\text { Three- } \\
\text { dimensional } \\
\text { grammar } \\
\text { teaching } \\
\text { (Class 2) }\end{array}$} & Pair 1 & 1.000 & 1.642 & .248 & 4.039 & 43 & .000 \\
\hline & Pair 2 & 2.159 & 2.551 & .385 & 5.614 & 43 & .000 \\
\hline & Pair 3 & 3.159 & 3.778 & .570 & 5.546 & 43 & .000 \\
\hline & Pair 4 & 1.156 & 1.930 & .288 & 4.016 & 44 & .000 \\
\hline & Pair 5 & .622 & 1.862 & .278 & 2.241 & 44 & .030 \\
\hline & Pair 6 & 1.778 & 3.437 & .512 & 3.470 & 44 & .001 \\
\hline
\end{tabular}

In Table 11, pair 1 refers to part 1 of both the immediate posttest and the delayed posttest of Class 1 , pair 2 is part 2 of the two posttests of Class 1, and pair 3 means both two parts of the immediate posttest and the delayed posttest of Class 1. Pair 4, pair 5 and pair 6 are the same as pair 1, pair 2 and pair 3, which refer to Class 2 . We can tell that the Sig. (2-tailed) of Class 2 in paired-samples t test is 0.001 and Class 1 is 0.000 , which are both smaller than 0.05 . Thus, there is a significant difference. 


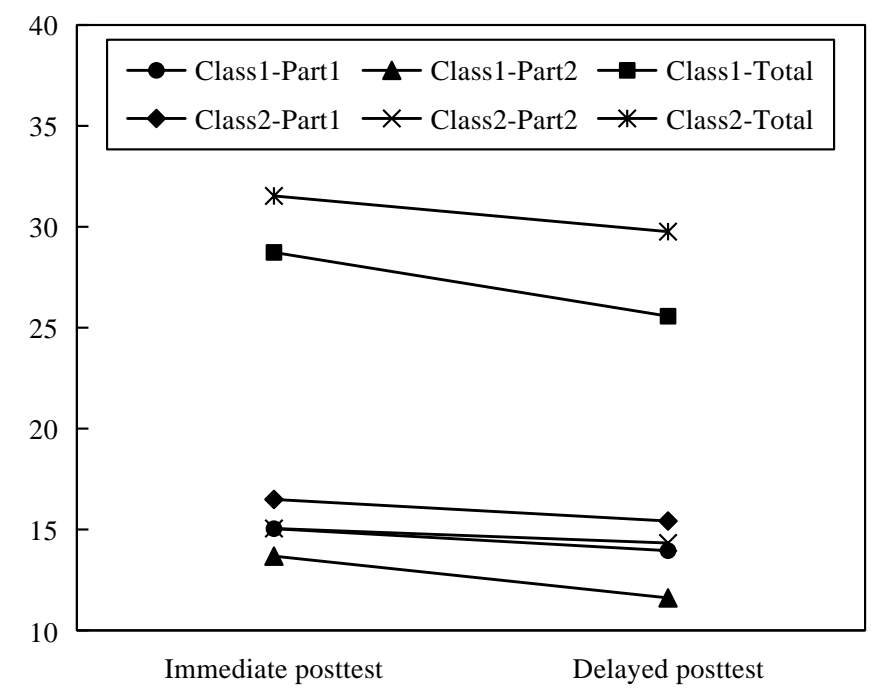

Figure 4. Comparison of Immediate Posttest and Delayed Posttest

The differences between the immediate posttest and the delayed posttest in two classes show directly and clearly the effectiveness of three-dimensional grammar teaching. In terms of Figure 4, the mean gap in Class 2 is smaller than that in Class 1, which implies that students in Class 2 outperform in the delayed posttest after two weeks and they tend to have a longer and better retention in remembering target phrasal verbs, which reflects that the approach of three-dimensional grammar has a greater impact on retention. Therefore, it can be drawn that three-dimensional grammar teaching is more effective for Chinese middle school students to acquire English phrasal verbs than conceptual metaphor teaching.

\section{Results of Questionnaires}

Among the 45 questionnaires that were sent out, 45 were collected and 45 were valid. The Cronbach's alpha of the questionnaire is 0.788 , indicating that this questionnaire scale is of internal consistency and high reliability.

From question one to question three, it can be summarized that more than $29 \%$ of the students think it difficult to learn phrasal verbs. About $47 \%$ of the students do not have interest in learning phrasal verbs, and some learn phrasal verbs just for the requirement of exams, which reveal that they do not realize the important role of phrasal verbs in English learning. As for the results of the next five questions, it can be seen that about $76 \%$ of the students enjoy the teaching approach of three-dimensional grammar who believe that with the help of this approach, they are more interested in learning phrasal verbs. They are more willing to participate in various classroom interactions. But there are still $6 \%$ of the students do not have particular preference to get involved in the class actively and reckon that this teaching approach is dull. According to the percentages of questions nine to twelve, more than $74 \%$ of the students hold the view that three-dimensional grammar teaching does good to their learning of vocabulary and writing. Besides, their oral communication skills have also been improved. While 7\% of the students think it has little effect on their English learning. They have no enthusiasm to use the new learned phrasal verbs. And on the basis of the results of question thirteen to question fifteen, which have shown students' general feelings and hopes towards the teaching and learning in English lessons, about 86\% of the students deem that three-dimensional grammar teaching makes them more interested in learning English phrasal verbs and they have confidence in their future English study, who also hope that in the future English class, more and more various activities related to their daily life or their interests should be provided. However, on the other hand, there are about $4 \%$ of the students still think three-dimensional grammar teaching has no special effect on the phrasal verbs learning and even English learning.

\section{F. Discussion}

From the results of the immediate posttests, it can be found that Class 2 instructed with three-dimensional grammar teaching approach outperforms Class 1. Effective output is a crucial part of output driven hypothesis, and the last step of three-dimensional grammar teaching in this experiment is to output with lots of practice. Namely, in Class 2, after knowing the meanings of the particles and the phrasal verbs, students were asked to work in pairs and to make oral communication by using the phrasal verbs they have already learned for the reinforcement, and they could better understand how to use the particles correctly and output the proper phrasal verbs in certain contexts. As a contrast, students in Class 1 were asked to draw their own pictures but not practice the phrasal verbs they have learned.

According to the results of the delayed posttests, the students in Class 2 get higher scores, and they are more retentive in remembering target phrasal verbs effectively, which reveal that three-dimensional grammar teaching has a greater impact on long term retention. In Class 2, students were requested to use the phrasal verbs in order to reinforce the understanding. During the period of group work, the forms and meanings of the particles and phrasal verbs were used many times, which can leave a deep impression on the students. Therefore, in the delayed posttest, students could recall the scene of interactions and the experiences related to practicing the target phrasal verbs they had in class, and performed better on the 
delayed posttest.

Besides, in terms of Figure 4, in the second part (translation questions) of the two tests, the mean gap of Class 2 is smaller than that of Class 1, indicating that students in Class 2 remembered the target phrasal verbs better than students in Class 1 and forgot them more slowly. The reason is that in classroom teaching, students in Class 2 practiced and produced the target phrasal verbs through making dialogues, and then they had a better retention of the target phrasal verbs. However, students in Class 1 did not produce the target phrasal verbs they had learned, so they didn't remember the target phrasal verbs as well as students in Class 2.

What is more, student Zhang in Class 2 said that "Before that, I thought English phrasal verbs were very difficult to remember and they were not used in oral practice. But in this semester, my teacher taught us English phrasal verbs and asked us to practice them more, I could understand their meanings better and use them more accurately than before." This also reflects that students like the teaching approach based on three-dimensional grammar.

\section{CONCLUSION}

Research questions put forward in this study are answered as follows: Three-dimensional grammar teaching is more effective than conceptual metaphor teaching for Chinese middle school students to acquire English phrasal verbs and the application of three-dimensional grammar teaching can effectively improve their retention of English phrasal verbs. Furthermore, students are fond of three-dimensional grammar teaching approach in classroom teaching, and this teaching approach positively affects their learning of phrasal verbs, and they are willing to take part in practice related to the phrasal verbs in English class.

\section{LiMitATIONS AND SUGGESTIONS OF THE STUDY}

First of all, the particles of the target phrasal verbs studied in this paper are only limited to "up" and "out". Future research could choose more particles to further check the effectiveness of two different teaching approaches based on three-dimensional grammar and conceptual metaphor theory.

In addition, if the students instructed by conceptual metaphor teaching were also asked to practice the phrasal verbs they learned just the same as students instructed by three-dimensional grammar teaching, then which teaching approach is more effective?

\section{ACKNOWLEDGMENTS}

This paper was sponsored by a grant from Social Science Foundation, Hunan Province, China. The project number is 17YBA089.

\section{REFERENCES}

[1] Boers, F. (2004). Expanding Learners' Vocabulary through Metaphor Awareness: What Expansion, What Learners, What Vocabulary? In M. Achard \& S. Niemeier (eds.) Cognitive Linguistics, Second Language Acquisition, and Foreign Language Teaching. Berlin, Germany: Mouton de Gruyter, 211-232.

[2] Bolinger, D. (1971). The Phrasal Verbs in English. London: Oxford University Press.

[3] Chan, T. P. \& Liou, H. C. (2005). Effects of Web-based Concordancing Instruction on EFL Students' Learning of Verb-noun Collocations. Computer Assisted Language Learning 18, 231-251.

[4] Ellis, R. (2001). Introduction: Investigating Form-focused Instruction. Language Learning 51, 1-46.

[5] Gao Ruifang. (2021). The Vocabulary Teaching Mode Based on the Theory of Constructivism. Theory and Practice in Language Studies 11, 442-446.

[6] Gibbs, R. W. (1990). Psycholinguistic Studies on the Conceptual Basis of Idiomaticity. Cognitive Linguistics 1, 417-451.

[7] Hao Huanhuan. (2018). Application of Context Based on Three-dimensional Grammar Teaching in Senior High School. M.A. thesis, Nanjing Normal University.

[8] Lakoff, G. (1987). Women, Fire, and Dangerous Things. Chicago: University of Chicago Press.

[9] Langacker, R. (1992). Foundations of Cognitive Grammar. Stanford, CA: Stanford University Press.

[10] Larsen-Freeman. (2003). Teaching Language: From Grammar to Grammaring. Boston: Heinle \& Heinle.

[11] Lightbown, P. (2000). Anniversary Article: Classroom SLA Research and Second Language Teaching. Applied Linguistics 9 , 431-462.

[12] Liviero Sara. (2017). Grammar Teaching in Secondary School Foreign Language Learning in England: Teachers' Reported Beliefs and Observed Practices. Language Learning Journal 45, 26-50.

[13] Long. (1991). Focus on Form: A Design Feature in Language Teaching Methodology. In K. de Bot, R. Ginsberg \& C. Kramsch (eds.), Foreign Language Research in Cross-Cultural Perspective. Amsterdam: John Benjamin.

[14] Lu Yanfang. (2021). The Analysis of the Features of Interaction in Instructed SLA. Theory and Practice in Language Studies 11, 447-456.

[15] Luo Misi. (2020). Junior High School Students' Acquisition of English Phrasal Verbs from the Prospective of Conceptual Metaphor Theory. M.A. thesis, Hunan University.

[16] Nippold, M. A. (1998). Later Language Development: The School-age and Adolescent Years. Austin, TX: Pro-Ed.

[17] Song Haishu. (2019). Action Research on Relative Clause Teaching in High School English Based on Three-dimensional Grammar. M.A. thesis, Ningbo University. 
[18] Sun, Y. C. \& Wang, L.Y. (2003). Concordancers in the EFL Classroom: Cognitive Approaches and Collocation Difficulty. Computer Assisted Language Learning 16, 83-94.

[19] Swain, M. (1985). Communicative Competence: Some Roles of Comprehensible Input and Comprehensible Output in Its Development. In S. Gass \& C. Madden (eds.) Input in Second Language Acquisition. Rorley Mass: Newbury House, 64-81.

[20] Veliz, L. (2017). A Route to the Teaching of Polysemous Lexicon: Benefits from Cognitive Linguistics and Conceptual Metaphor Theory. Journal of Basic and Applied Scientific Research 7(1), 211-217.

[21] Wang Yiying. (2020). A Survey of the Use of English Vocabulary Mnemonic Strategies by Non-English Majors. Theory and Practice in Language Studies 10, 1656-1661.

[22] Wen Qiufang. (2013). Application of Output-driven Hypothesis in College English Teaching: Reflections and Suggestions. Foreign Language World 6, 14-22.

[23] White, B. J. (2012). A Conceptual Approach to the Instruction of Phrasal Verbs. Modern Language Journal 96(iii), $419-438$.

[24] Wilkins, D. (1972). Linguistics and Language Teaching. London: Edward Arnold.

Mingxing Tao was born in Gansu Province, China in 1968. He received his PhD degree in Foreign Language and Literature from School of Foreign Languages of Hunan University in Hunan, China in 2019. Now he is an associate professor at School of Foreign Languages of Hunan University. He is a visiting scholar in Yale University. His research interest is English language teaching.

Jiaxin Wang was born in Henan Province, China in 1998. She is now studying for her M.A degree in English Language Teaching at School of Foreign Languages of Hunan University, Hunan Province, China. 